\title{
Innovation Ecosystems: A Sustainability Perspective
}

\author{
António Abreu ${ }^{1,2}$ (D) \\ 1 Department of Mechanical Engineering, Polytechnic Institute of Lisbon, 1959-007 Lisboa, Portugal; \\ ajfa@dem.isel.ipl.pt \\ 2 CTS Uninova, 2829-516 Caparica, Portugal
}

check for updates

Citation: Abreu, A. Innovation Ecosystems: A Sustainability Perspective. Sustainability 2021, 13, 1675. https://doi.org/10.3390/ su13041675

Academic Editor: Marc A. Rosen

Received: 6 January 2021

Accepted: 4 February 2021

Published: 6 February 2021

Publisher's Note: MDPI stays neutral with regard to jurisdictional claims in published maps and institutional affiliations.
In the last decade, the increasing globalization of markets and revolution 4.0, has caused profound changes in the best way to manage the innovation process. The innovation methods of the past are not well adapted to the turbulence of the modern world.

In order to be competitive, companies must develop capabilities that will allow them to react rapidly to market demands.

The development of new complex products/services requires access to a distinct set of resources and skills that companies do not normally have. Thus, in order to ensure their level of competitiveness, companies are confronted with the following dilemma: to develop the skills and resources needed from their own assets, they sometimes need to make significant investments, or, alternatively, use the skills and resources that can be made available by other companies in the context of an innovation ecosystem.

However, despite the fact that collaboration among companies in an innovation ecosystem had been considered unusual and indeed suspicious by many Small and Medium Enterprise (SME) managers until a few years ago, nowadays it is commonly assumed that many companies will participate in an innovation ecosystem. Literature in the field has pointed out that participating in an innovation ecosystem brings benefits to the involved entities. Underlying these expectations are, amongst others, the following factors: the sharing of risks and resources, the joining of complementary skills and capacities, and access to new/wider markets and new knowledge.

In fact, there is an intuitive assumption that, when a company is a member of a long-term networked structure, it will operate more effectively in pursuit of its goals.

However, it has been difficult to support this assumption due to the lack of models that support mechanisms explaining innovation processes in an innovation ecosystem environment.

This e-book comprises an edition of the Special Issue entitled "Innovation Ecosystems: A Sustainability Perspective", published by the journal Sustainability, and includes a collection of thirteen papers that discuss theoretical approaches, case studies, and surveys focused on issues related to open innovation and its mechanisms in order to support the promotion and sustainability of innovation ecosystems.

Concerning theoretical contributions, Jütting, in a systematic literature review, explores and conceptualizes the idea of mission-oriented innovation ecosystems and presents a typology [1]

Dias et al. propose a functional holistic model which integrates the strategic, organizational, and operational levels, as well as a set of factors to take into account supporting innovative processes [2]. Based on the Panarchy model that describes the evolutionary nature of complex adaptive systems, Boyer proposes an evolutionary and sustainability perspective of the innovation ecosystem [3].

Santos et al. introduce a framework to evaluate the risk level of system development in open innovation environment based on a fuzzy logic approach [4]. Nunes and Abreu propose an open innovation risk management model based on concepts from social network analysis to estimate the outcome likelihood (success or failure) of ongoing open innovation projects [5]. 
Munodawafa and Johl, based on results achieved from a systematic literature review of eco-innovation, suggest that organizational stakeholders, resources, and capabilities are critical factors in the definition of an innovation strategy. Furthermore, the authors conclude that resource-based and stakeholder theories are frequently utilized to explain eco-innovation processes [6].

Sarri et al. introduce a new methodological proposal to help the development of smart management as a means to support the progressive development of technological innovations and their adoption in wine farms [7].

Zandebasiri et al. discuss the advantages of using Multi-Criteria Decision Making (MCDM) methodologies supported by concepts from game theory in decision-making processes to ensure sustainable forest management [8].

Regarding studies and surveys, Costa and Matias discuss how open innovation can improve sustainable innovation ecosystems and drive the digital transition [9].

Wurster et al. discuss the results of a survey conducted in Germany with the purpose of creating an empirical foundation for the specification of software for sustainable automotive products, particularly sustainable tyres [10].

Yang et al. analyze the formation and evolution of BIM in China from the perspective of an innovation ecosystem [11]. Chaminade and Randelli, in their work. analyze the role of innovation ecosystems as a driver of wine industry transformation in the Panzano region [12].

Yordanova et al., in their work, analyze the role of a university in the development of technopreneurial intentions among Bulgarian STEM (STEM refers to any subjects that fall under the disciplines of science, technology, engineering, or mathematics) students [13].

Last but not least, as the guest editor of this e-book, I would like to express my profound gratitude for the opportunity to publish with MDPI. This acknowledgment extends to the Sustainability Editorial Office and especially to Mrs. Debbie Li, who has supported me constantly throughout this process.

It was a great pleasure to work in such conditions. I look forward to collaborating with the Sustainability journal in the future.

Funding: This research received no external funding.

Institutional Review Board Statement: Not applicable" for studies not involving humans or animals. Informed Consent Statement: "Not applicable" for studies not involving humans.

Data Availability Statement: Not applicable.

Conflicts of Interest: The author declares no conflict of interest.

\section{References}

1. Jütting, M. Exploring Mission-Oriented Innovation Ecosystems for Sustainability: Towards a Literature-Based Typology. Sustainability 2020, 12, 6677. [CrossRef]

2. Dias, A.S.M.E.; Abreu, A.; Navas, H.V.G.; Santos, R. Proposal of a Holistic Framework to Support Sustainability of New Product Innovation Processes. Sustainability 2020, 12, 3450. [CrossRef]

3. Boyer, J. Toward an Evolutionary and Sustainability Perspective of the Innovation Ecosystem: Revisiting the Panarchy Model. Sustainability 2020, 12, 3232. [CrossRef]

4. Santos, R.; Abreu, A.; Dias, A.; Calado, J.M.F.; Anes, V.; Soares, J. A Framework for Risk Assessment in Collaborative Networks to Promote Sustainable Systems in Innovation Ecosystems. Sustainability 2020, 12, 6218. [CrossRef]

5. Nunes, M.; Abreu, A. Managing Open Innovation Project Risks Based on a Social Network Analysis Perspective. Sustainability 2020, 12, 3132. [CrossRef]

6. Munodawafa, R.T.; Johl, S.K. A Systematic Review of Eco-Innovation and Performance from the Resource-Based and Stakeholder Perspectives. Sustainability 2019, 11, 6067. [CrossRef]

7. Sarri, D.; Lombardo, S.; Pagliai, A.; Perna, C.; Lisci, R.; De Pascale, V.; Rimediotti, M.; Cencini, G.; Vieri, M. Smart Farming Introduction in Wine Farms: A Systematic Review and a New Proposal. Sustainability 2020, 12, 7191. [CrossRef]

8. Zandebasiri, M.; Filipe, J.A.; Soosani, J.; Pourhashemi, M.; Salvati, L.; Mata, M.N.; Mata, P.N. An Incomplete Information Static Game Evaluating Community-Based Forest Management in Zagros, Iran. Sustainability 2020, 12, 1750. [CrossRef] 
9. Costa, J.; Matias, J.C.O. Open Innovation 4.0 as an Enhancer of Sustainable Innovation Ecosystems. Sustainability 2020, $12,8112$. [CrossRef]

10. Wurster, S.; Heß, P.; Nauruschat, M.; Jütting, M. Sustainable Circular Mobility: User-Integrated Innovation and Specifics of Electric Vehicle Owners. Sustainability 2020, 12, 7900. [CrossRef]

11. Yang, Y.; Zhang, Y.; Xie, H. Exploring Cultivation Path of Building Information Modelling in China: An Analysis from the Perspective of an Innovation Ecosystem. Sustainability 2020, 12, 6902. [CrossRef]

12. Chaminade, C.; Randelli, F. The Role of Territorially Embedded Innovation Ecosystems Accelerating Sustainability Transformations: A Case Study of the Transformation to Organic Wine Production in Tuscany (Italy). Sustainability 2020, $12,4621$. [CrossRef]

13. Yordanova, D.; Filipe, J.A.; Pacheco Coelho, M. Technopreneurial Intentions among Bulgarian STEM Students: The Role of University. Sustainability 2020, 12, 6455. [CrossRef] 